\title{
Faktor yang Mempengaruhi Pengembangan Klaster Batik Laweyan-Surakarta Menuju Ekonomi Lokal Berkelanjutan
}

\author{
Abdul Muin ${ }^{1}$ \\ Dinas Tenaga Kerja Transmigrasi dan Sosial \\ Kota Magelang, Indonesia
}

\begin{abstract}
Abstrak: Kondisi ekonomi Kampung Batik Laweyan Surakarta sebagai klaster ekonomi masih belum cukup baik dibanding masa kejayaannya tahun 1970an meskipun sudah ada peningkatan sejak 2004. Kini kawasan itu tengah mendapat banyak perhatian masyarakat dan pemerintah. Bahkan banyak pakar telah mengulas keberadaannya yang merupakan gambaran bahwa kawasan ini begitu penting dan layak untuk dikembangkan. Untuk dapat mengembangkan klaster hingga tercapai proses ekonomi yang berkelanjutan, maka perlu diketahui faktor utama yang mempengaruhinya. Faktor itu dapat berupa kondisi dan kegiatan yang merupakan kendala dan potensinya. Ada faktor yang diketahui secara umum, namun ada pula faktor yang khusus ada di Kampung Batik Laweyan, dan untuk mengetahuinya maka dilakukan penelitian ini. Dalam menentukan variabel yang akan diteliti maka dilakukan dengan mengambil faktor dari teori yang dinyatakan oleh beberapa pakar (pendekatan positivistik), dipadukan dengan variabel dalam hasil penelitian sebelumnya (pendekatan rasionalistik). Penelitian dilakukan dengan metode kuantitatif dengan mencari sebanyak mungkin pendapat pengusaha dan menyimpulkannya secara umum sebagai gambaran mengenai faktor yang menjadi persepsi seluruh pengusaha yang ada di kawasan tersebut. Dari 25 variabel yang dipertanyakan terhadap pelaku usaha, dengan analisis faktor dihasilkan bahwa terdapat 7 (tujuh) faktor yang paling berpengaruh terhadap pengembangan klaster Batik Laweyan menuju ekonomi lokal berkelanjutan yaitu faktor kinerja pengusaha (13,79\%), dukungan pemerintah daerah (13,27\%), pemanfaatan sumber daya (11,97\%), manajemen perusahaan $(11,59 \%)$, karakteristik sosial $(9,62 \%)$, kekuatan bisnis lokal $(9,14 \%)$ dan pembelian non lokal (5,30\%). Faktor kinerja pelaku usaha memiliki variabel utama berupa tindakan bersama untuk kepercayaan serta kaderisasi. Ini menunjukkan bahwa yang paling penting untuk mendapat perhatian adalah pengusahannya.
\end{abstract}

Kata Kunci: analisis faktor, ekonomi berkelanjutan, klaster, pengembangan ekonomi lokal, persepsi pelaku usaha

\begin{abstract}
Condition of economics of Kampung Batik Laweyan Surakarta as Klaster economics still have not good enough yet compared to a period of its glory in 1970 though there are improvements since 2004. Now it is having much attention of public and government. Even many experts have commented the existence that this area is so important and competent to be developed. To be able to develop cluster in order to reach the sustainable economics process, it is important to know the primary factor that influencing it. The factors can be in the form of condition and activity which is its constraint and potency. There are factors known in general, but also special factor at Kampung Batik Laweyan, and to know it hence done by this research. In determining variable which will be checked hence done by taking factor from theory that expressed by some expert (positivistic approach) allied by variable in
\end{abstract}

\footnotetext{
${ }^{1}$ Korespondensi Penulis: Disnakertransos Kota Magelang

Email:: abdulmuin_mpwk@yahoo.co.id
} 
result of research before (rationalistic approach). Research is done with quantitative method with looking for as many as possible opinion of the entrepreneur and conclude it in general as image of about factor that becomes perception of all entrepreneur the in the area. Out of 25 variables questioned to the entrepreneur, with factor analysis yielded, there are 7 (seven) factors which very influential to the development of Batik Laweyan cluster towards having sustainable local economics including entrepreneur performance factor (13,79\%), support from local government (13,27\%), resource exploiting (11,97\%), company management $(11,59 \%)$, social characteristic $(9,62 \%)$, strength of local business $(9,14 \%)$ and non local purchasing $(5,30 \%)$. Entrepreneur performance factor property of main variable in the form of action with trust and also regeneration. It indicates the most important to be considered is the entrepreneur.

Keywords: cluster, factor analysis, local economic development, perception of entrepreneur, sustainable economic

\section{Pendahuluan}

\section{Latar Belakang}

Kampung Batik Laweyan merupakan Klaster Batik di Kelurahan Laweyan, Kecamatan Laweyan, Kota Surakarta. Di sana ada ratusan perusahaan pembuat batik dengan berbagai ukuran/skala usaha. Ada beberapa yang besar, ada puluhan perusahaan sedang, dan ratusan perusahaan kecil sampai dengan rumahan. Namun saat ini kondisi perekonomian klaster ini tidak begitu memuaskan jika dibandingan masa kejayaannya sebagai sentra industri batik tahun 1970an meskipun sudah ada peningkatan pada awal tahun 2004 yang lalu.

Keadaan Kampung Batik Laweyan ini telah mendapat banyak perhatian masyarakat yang dibuktikan dengan pembentukan Forum Pengembangan Kampoeng Batik Laweyan Surakarta, ulasan di surat kabar terutama terbitan lokal dan regional serta munculnya website yang secara intensif menginformasikan aktivitas ekonomi, budaya maupun aspek lain di kawasan itu. Perhatian Pemerintah Kota Surakarta sangat besar, melalui kegiatan di Dinas Perindustrian Perdagangan dan Penanaman Modal, penetapan sebagai Kawasan Kuno Bersejarah (1997) dan pembentukan Panitia Pembentukan Kawasan Batik Laweyan Kota Surakarta (2004) serta Penetapan Lokasi pembangunan Instalasi Pengolahan Air Limbah (IPAL) Kampung Batik Laweyan (2006). Banyak pakar mengulas keberadaan kawasan ini, misalnya Siswanti (2007) meneliti faktor yang mempengaruhi perkembangan industri batiknya. Lalu Murti (2010) membahas peran pemerintah daerah dalam pengembangan klaster itu, Harjanto dan Untari mengulas artikel "Kampong Batik Laweyans Conditions Supporting Cluster Development", serta Widodo (2011) mengidentifikasi bentuk penerapapn eko-efisiensi pada klaster tersebut, dan Kusumandari (2011) yang mengkaji karakteristiknya sebagai kampung tradisional dan masih banyak lagi.

Begitu banyak perhatian dari berbagai kalangan diberikan kepada Kampung Batik Laweyan ini, dikarenakan pentingnya keberadaan kawasan ini. Dari hal itu dapat disimpulkan bahwa kawasan ini begitu penting dan layak untuk dikembangkan.

\section{Permasalahan}

Pengembangan kawasan tersebut harus dilakukan agar dapat berkelanjutan, dan tentunya ada faktor-faktor yang mempengaruhinya. Selama ini permasalahan terjadi hingga sulit untuk melihat ujung pangkalnya, sulit melihat faktor apa yang paling besar pengaruhnya, apa yang paling mendesak harus diselesaikan, maupun potensi yang dimilki yang punya peluang besar untuk segera bisa menyelesaikan permasalahannya. Yang diketahui hanyalah 
akibatnya, bahwa kondisi klaster yang tidak seperti harapan, apalagi dibandingkan dengan masa kejayaannya dulu.

Penelitian ini dimaksudkan untuk mendapatkan gambaran kendala dan potensinya dalam rangka pembangunan ekonomi lokal yang berkelanjutan dari persepsi pelaku usaha. Penelitian ini akan berusaha menjawab pertanyaan berikut:

"Faktor-faktor apa yang mempengaruhi pengembangan Klaster Batik Laweyan Surakarta menuju ekonomi lokal berkelanjutan?"

Pertanyaan utama tersebut dapat dipisahkan sebagai berikut:

a) Bagaimana kondisi ekonomi dan aktivitas ekonomi di kawasan/lokal itu?

b) Faktor apakah yang mempengaruhi pengembangan ekonomi lokal pada klaster Batik Laweyan Surakarta menuju ekonomi yang berkelanjutan?

c) Bagaimana pengembangannya berdasarkan faktor-faktor yang ditemukan?

\section{Metode Penelitian}

Untuk melaksanakan penelitian ini dipakai metode penelitian kuantitatif. Metode ini menggunakan data numerik atau yang dinumerikkan untuk dianalisis. Dalam penelitian ini metode pendekatan untuk mendapatkan variabel penelitian yang digunakan adalah positivistik dan rasionalistik. Kombinasi dua pendekatan itu menghasillkan variabel untuk diuji keberadaannya di lokasi studi.

Data yang dianalisis adalah data kuantitatif. Sementara hasil uji variabel adalah persepsi (yang bersifat kualitatif) dari responden mengenai variabel yang dikuantisasi untuk memenuhi kebutuhan data. Data ini diperoleh dari sebanyak mungkin responden (pengusaha) yang diharapkan dapat mewakili persepsi populasi. Teknik pengumpulan data yang dilaksanakan adalah survei melalui kuesioner dengan cara meminta penilaian responden atas keberadaan faktor tersebut dengan memilih sikap persetujuan.

Dalam pengolahan data survei, setelah pemeriksaan data dan editing serta pembuatan ketentuan pemberian kode, data disederhanaan sesuai Skala Likert menjadi 5 kategori yaitu sangat setuju, setuju, tidak tahu, tidak setuju serta sangat tidak setuju.

Untuk sampling, dipilih teknik porportionate stratified accidental sampling karena populasi memiliki kelompok dengan karakter berbeda, juga agar tidak didominasi oleh kelompok populasi tertentu dan jika responden yang direncanakan gagal maka dicari responden lain dengan prioritas dari kelompok populasi yang sama. Jumlah sampel sesuai ketentuan Slovin (dalam Kusmayadi dan Sugiarto, 2000), jumlah sampel adalah:

$$
\mathrm{n}=\mathrm{N} /\left(1+\mathrm{N}^{\star} \mathrm{e}^{\wedge} 2\right)
$$

dengan $\mathrm{n}=$ jumlah sampel; $\mathrm{N}=$ jumlah populasi; $\mathrm{e}=$ margin eror (umumnya $5-10 \%$ ).

Dengan $(\mathrm{e})=10 \%$, dan populasi 70 pengusaha, maka didapatkan bahwa jumlah sampelnya sebanyak 42 .

\section{Kondisi dan Aktivitas Ekonomi Lokal Kampung Batik Laweyan}

\section{Kondisi Ekonomi Kelurahan Laweyan}

Kesejahteraan penduduk Kelurahan Laweyan terlihat pada komposisi keluarganya yang tahun 2010 adalah sebagai berikut: 122 pra sejahtera, 143 sejahtera I, 92 sejahtera II, 76 sejahtera III, 57 keluarga sejahtera III + (plus). Di bidang permukiman, dari sejumlah total 587 rumah yang ada, 4 rumah non permanen dan 583 permanen dengan 20 rumah di bantaran sungai. Sarana ibadah dan pendidikan di kawasan tersebut terdiri 4 masjid dan 4 mushola serta 1 buah SD.

Kegiatan yang lebih besar ada di sektor Industri Batik. Sektor ini dapat menjadi potensi untuk menggerakkan ekonomi masyarakat.Permasalahan secara umum yang 
terjadi adalah perkembangannya yang fluktuatif dan belum bisa optimal sebagaimana mereka pernah mengalami masa kejayaannya.

\section{Sejarah Klaster Batik Laweyan}

Menurut Ketua RT Mlayadipuro, sejarah kawasan Laweyan dimulai Kyai Ageng Anis (Kyai Ageng Laweyan) bermukim di desa itu tahun $1546 \mathrm{M}$. Pasar Laweyan dulunya merupakan Pasar Lawe (benang bahan baku tenun) yang sangat ramai. Lokasinya di desa Laweyan. Di selatan Pasar Laweyan, di tepi sungai Kabanaran, terdapat Bandar Kabanaran yang terhubung ke Bandar Besar Nusupan di tepi sungai Bengawan Solo.

Pada tahun 1911 Serikat Dagang Islam (SDI) didirikan di Kampung Laweyan oleh Kyai Haji Samanhudi. Tahun 1935 para saudagar batik Laweyan merintis pergerakan koperasi dengan didirikannya "Persatoean Peroesahaan Batik Boemipoetra Soerakarta (PPBBS)". Inilah masa kejayaan Kampung Batik Laweyan Surakarta. Sejak saat itu Kampung Laweyan mengalami masa surut.

Pada periode 1970-an hingga awal tahun 2000-an, industri batik di Kampung Laweyan memang mati suri karena serbuan batik printing dari Cina. Sebagian besar bangunan kuno tempat tinggal para saudagar menjadi tak terawat, kumuh dan rusak. Selama lebih dari 30 tahun bisnis batik di Laweyan terputus. Batik yang sudah dikenal sejak abad ke-19 di kampung ini pun seperti terkubur. Masa kejayaan batik Laweyan yang pernah terjadi pada era tahun 1930-an tinggal cerita lama (Ganug, 2012).

\section{Gambaran Aktivitas dan Perkembangan Klaster}

Sesuai dengan penuturan Ganug, 2012, pada tahun 2003 lalu Laweyan mulai digagas sebagai kampung wisata batik dengan cara menghidupkan batik kembali dengan konsep pariwisata. Pada tahun 2004 Pemerintah Kota Surakarta mewujudkan gagasan itu dan mematenkan 215 motif batik dari Laweyan. Saat itu berdirilah Forum Pengembangan Kampoeng Batik Laweyan (FPKBL), forum pemberdayaan warga Laweyan dalam mengembangkan pariwisata berbasis industri batik dan nonbatik di kawasan ini. Kini Kampung Batik Laweyan seluas 24 ha ini telah menjadi kampung batik terpadu: tradisi membatik, heritage dan wisata belanja.

Dengan pembentukan Kampung Batik Laweyan menjadi sebuah klaster maka manfaatnya sangat terasa dalam mengembangkan industri batik dan usaha terkait batik di kawasan tersebut. Seperti diungkapkan dalam kompas.com oleh Pudjiastuti dan Sawega (2009), bahwa pada tahun 2004 pengusaha batik di Laweyan tercatat 22 orang. Pada tahun 2009 meningkat menjadi 56 orang. Dalam kurun waktu tersebut, pendapatan masyarakat Laweyan juga meningkat sampai sekitar 200 persen. Pada tahun 2012, penulis mendapati data terakhir perkembangan usaha batik di Laweyan sebagai berikut:

Tabel 1. Jumlah Populasi Tiap Kelompok

\begin{tabular}{|c|c|c|c|c|}
\hline No. & Klasifikasi Kegiatan Usaha & Kecil & Menengah & Besar \\
\hline 1 & Ind.B.Proses s/d Showroom & 4 & 13 & 3 \\
\hline 2 & Ind.B.Proses & 1 & 5 & 0 \\
\hline 3 & Ind.B.Konfeksi & 4 & 0 & 0 \\
\hline 4 & Ind.B.Konfeksi - Showroom & 8 & 2 & 0 \\
\hline 5 & Showroom Batik & 18 & 4 & 0 \\
\hline \multirow[t]{2}{*}{6} & Industri Non Batik & 8 & 0 & 0 \\
\hline & JUMLAH & 43 & 24 & 3 \\
\hline
\end{tabular}

Pengunjung yang datang ke Laweyan pada liburan tahunan umumnya dari Jakarta, Bandung, Surabaya, Medan hingga Batam. Untuk liburan akhir minggu yang panjang biasanya dari Jakarta, Bandung, Surabaya dan Semarang. Jangkauan pemasaran batik ini 
sudah sampai ke area nasional dengan adanya showroom di kota lain seperti Jakarta, Bandung, Surabaya, Medan, Batam dan lain-lain bahkan ekspor.

\section{Pengembangan Ekonomi Lokal Berkelanjutan}

\section{Pembangunan Berkelanjutan dan Pengembangan Ekonomi Lokal}

Untuk dapat berkelanjutan, pembangunan ekonomi perlu peduli terhadap aspek sosial (manfaat yang diperoleh bagi manusia) dan ekologi (kelestariannya sumber daya alam dan kualitas daya dukung lingkungan). Serageldin (1996) menyebutkan bahwa pembangunan dinyatakan berkelanjutan jika secara ekonomi, ekologi (lingkungan) dan sosial bersifat berkelanjutan.

Pengembangan lokal harus memperhatikan karakteristik lokal, dan mengoptimalkan pemanfaatan potensi dan pemberdayaan sumber daya lokal. Blakely (1994) menyebutkan bahwa ciri utama pembangunan ekonomi lokal adalah penekanan pada pengembangan endogen menggunakan sumber daya manusia potensial dan fisik setempat untuk menciptakan kesempatan kerja baru dan rangsangan ekonomi lokal baru. Pembentukan klaster merupakan tahapan strategis aktivitas ekonomi dalam kawasan dalam rangka pengembangan ekonomi lokal. Berawal dari aglomerasi (penyatuan lokasi beberapa kegiatan ekonomi), maka kemudian akan menjadi suatu klaster ketika memiliki ciri-ciri berikut: ada keterkaitan saling membutuhkan, ada kerjasama, ada peningkatan daya saing kolektif.

\section{Faktor yang Mempengaruhi Pengembangan Ekonomi Lokal}

Pengembangan klaster merupakan proses pengembangan ekonomi lokal sehingga harus juga memperhatikan faktor dalam pengembangan ekonomi lokal. Menurut Blakely (1994) ada 14 faktor yaitu: sumber daya alam, tenaga kerja, penanaman modal, kewirausahaan, transportasi, komunikasi, komposisi industri, teknologi, ukuran, pasar ekspor, situasi ekonomi internasional, kapasitas pemerintah daerah, belanja nasional dan belanja negara pemerintah dan pembangunan yang mendukung.

Menurut Blaire (1995) ada 6 faktor yaitu: komposisi industri, profesi, kependudukan, kepemilikan, pasar serta struktur politik dan sosial. Sementara menurut Phillips (1990) ada 11 faktor yaitu: globalisasi ekonomi, defisit perdagangan, pertumbuhan populasi dan angkatan kerja yang lebih lambat, peningkatan kekuatan partisipasi buruh oleh perempuan, pertumbuhan industri teknologi tinggi dan ekonomi berbasis ilmu/pengetahuan, kelebihan produksi dari barang komoditas dan hasil industri, perubahan alami dari ekonomi basis, ketidakstabilan ekonomi dan perusahaan, peningkatan kompetisi dan kerjasama dalam bursa kerja, persaingan antara dorongan usaha dan iklim usaha, pentingnya kerjasama pemerintah dan swasta yang meningkat. Sforzi (editor, 2003), dalam buku The Institutions of Local Development (kumpulan penelitian tentang pengembangan lokal), menyimpulkan adanya 3 kekuatan/faktor yang punya pengaruh besar yaitu: identitas lokal yang melekat, tindakan bersama untuk membentuk kepercayaan, modal sosial dalam pengembangan lokal. Haeruman (2001) menyebutkan faktor kemitraan yang juga disebutkan oleh UNDPUN Habibat-Bappenas (2002).

Siswanti (2007) dalam penelitiannya menyebutkan 5 faktor yang mempengaruhi perkembangan industri Batik Laweyan yaitu: manajemen keuangan, permodalan, produksi, sumber daya manusia serta pemasaran. Murti (2010) menambahkan faktor peran pemerintah, lalu Widodo (2011) menambahkan faktor penerapan eko-efisiensi, sedangkan Priyatmono (dalam Adi, 2012) menambahkan faktor alih generasi. 


\section{Faktor yang Mempengaruhi Pengembangan Klaster Batik Laweyan-Surakarta}

\section{Variabel Penelitian}

Dari keseluruhan faktor yang disebutkan oleh ahli dan peneliti maka ada 43 faktor. Tentu ada yang sama yang dimaksud oleh sumber yang satu dan sumber lainnya. Jika 43 faktor tadi semua dipertanyakan kepada responden maka pada pertanyaan-pertanyaan terakhir bisa kurang mendapat fokus perhatian hingga jawaban kurang bisa dipertangungjawabkan.

Maka faktor yang menjadi variabel penelitian dipilih 25 buah sebagai berikut:

- Faktor 1-14 dari Blakely (1994)

- Faktor 15-18 dari Siswanti (2007), 4 faktor menambah dan 1 faktor terwakili nomor 2.

- Faktor 19 dari Adhi Isa Murti (2010)

- Faktor 20 dari Nurrizki Dwianto Widodo (2011)

- Faktor 21 dari Haeruman (2001), Philips (1990), UNDP-UNHabitat-Bappenas (2002)

- Faktor 22-24 dari Sforzi (2003)

- Faktor 25 dari Priyatmono (2012), FPKBL Solo

Sejumlah 6 faktor yang disebutkan oleh Blair (1995) dan sejumlah 11 faktor yang disebutkan oleh Phillips (1990), dimasukkan dalam keterwakilan oleh faktor yang disebut sumber lain.

Faktor yang Mempengaruhi Pengembangan Klaster Batik Laweyan Surakarta menuju Ekonomi Lokal Berkelanjutan

\section{Deskripsi Data Hasil Sunei}

Dari survei yang dilakukan terhadap pelaku usaha dari perusahaan-perusahaan, didapatkan data hasil survei berupa persepsi pelaku usaha berupa persetujuan atas berpengaruhnya faktor yang diuji atas pengembangan Klaster Batik Laweyan menuju ekonomi lokal berkelanjutan. Dari 42 responden memberikan 1050 data terdistribusi dalam 5 kelompok penilaian yaitu 3 sangat tidak setuju, 52 tidak setuju, 99 tidak tahu, 501 setuju, dan 395 sangat setuju. Distribusi jawaban ini menggambarkan variabel yang dipertanyakan cenderung disetujui.

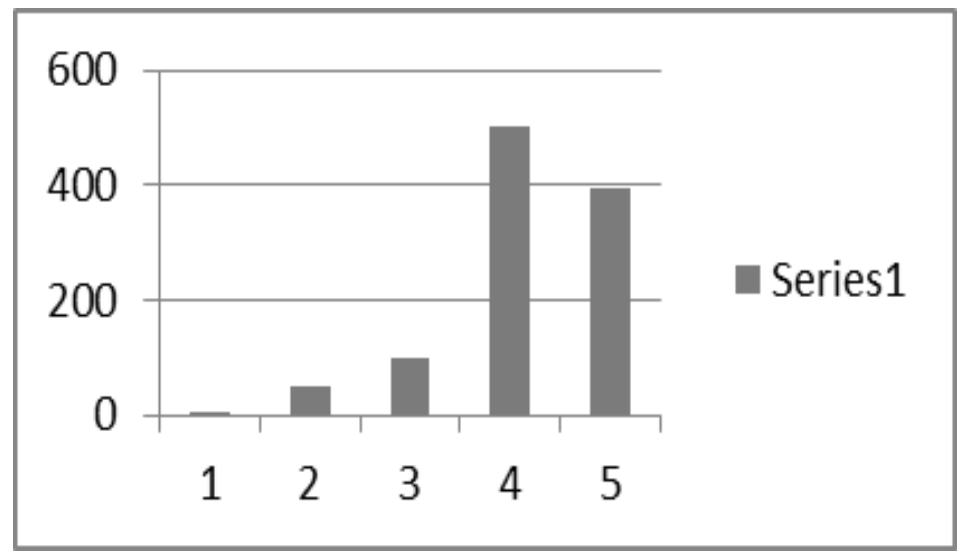

Sumber: Olahan Penulis dari Hasil Survei, 2012

\section{Gambar 1. Distribusi Persepsi Responden}




\section{Analisis Data Hasil Survei (R Factor Analysis)}

Dari data diatas digunakanlah analisis faktor. Teknik Analisis Faktor yang digunakan adalah $R$ Factor Analysis yang dilaksanakan tidak secara manual melainkan secara computerized dengan bantuan software program SPSS. Software SPSS yang digunakan adalah SPSS 16.0 Release.

Dari analisis yang dilakukan SPSS terhadap skor hasil survei dihasilkan gambaran statistik datanya (mean dan standar deviasinya) dan setelah diurutkan berdasar mean dari yang tertinggi dan berdasar standar deviasi dari yang terkecil, maka terlihat seperti dalam Tabel Descryptive Statistic di bawah.

Tabel 2. Descriptive Statistic

\begin{tabular}{l|r|r|r}
\hline \multicolumn{1}{c|}{ Faktor yg diuji } & Mean & \multicolumn{1}{c|}{ Std. Dev } & \multicolumn{1}{c}{ Anl. N } \\
\hline Identitas.Lokal & 4,52 & 0,552 & 42 \\
\hline Peran.Pemda & 4,50 & 0,672 & 42 \\
\hline Komunikasi & 4,48 & 0,634 & 42 \\
\hline Kewirausahaan & 4,45 & 0,550 & 42 \\
\hline Kaderisasi & 4,45 & 0,633 & 42 \\
\hline Dukungan.Pembangunan & 4,45 & 0,705 & 42 \\
\hline Sdm & 4,43 & 0,590 & 42 \\
\hline Transportasi & 4,43 & 0,770 & 42 \\
\hline Kemitraan.PSM & 4,33 & 0,612 & 42 \\
\hline Eko.Efisiensi & 4,31 & 0,643 & 42 \\
\hline Tindakan.Bersama & 4,26 & 0,665 & 42 \\
\hline Manajemen.Keuangan & 4,26 & 0,798 & 42 \\
\hline Modal.Sosbud & 4,24 & 0,726 & 42 \\
\hline Produksi & 4,21 & 0,750 & 42 \\
\hline Pemasaran & 4,21 & 0,951 & 42 \\
\hline Permodalan & 4,17 & 0,762 & 42 \\
\hline SDA & 4,17 & 0,853 & 42 \\
\hline Komposisi.Industri & 4,00 & 0,855 & 42 \\
\hline Tehnologi & 4,00 & 0,883 & 42 \\
\hline Pasar.Ekspor & 3,95 & 0,882 & 42 \\
\hline Kapasitas.Pemda & 3,88 & 0,739 & 42 \\
\hline Investasi & 3,74 & 0,939 & 42 \\
\hline Situasi.Ekonomi.Intl & 3,67 & 0,846 & 42 \\
\hline Ukuran.Klaster & 3,64 & 1,078 & 42 \\
\hline Belanja.Pemerintah & 0,939 & 42 \\
\hline
\end{tabular}

Sumber: output software SPSS 16.00, 2012

Dari tabel tersebut terlihat, mean tertinggi dimiliki oleh variabel identitas lokal (4.52) dan terendah dimiliki oleh variabel belanja pemerintah (3.60). Sejumlah 19 variabel disetujui dengan nilai mean $>=4$ dan 6 variabel mendapat skor 3,6 -3,95. Sementara standar deviasi tertinggi sebesar 1.078 diliki oleh variabel ukuran klaster dan terendah dimiliki oleh variabel kewirausahaan sebesar 0.550 .

\section{Uji Pemenuhan Syarat Analisis Faktor}

Analisis faktor mensyaratkan kecukupan data dan korelasi antar variabel yang dilihat dari nilai Measure of Sampling Adequacy uji KMO yang harus lebih dari 0,5 dan nilai significany uji Bartlett-nya yang harus lebih kecil dari 0,05. 
Tabel 2. KMO and Bartlett's Test

\begin{tabular}{l|l|r}
\hline \multicolumn{2}{c}{ KMO and Bartlett's Test } \\
\hline Kaiser-Meyer-Olkin Measure of Sampling Adequacy. & .552 \\
\hline \multirow{3}{*}{ Bartlett's Test of Sphericity } & Approx. Chi-Square & 671.320 \\
\cline { 2 - 3 } & Df & 300 \\
\cline { 2 - 3 } & Sig. & .000 \\
\hline
\end{tabular}

Sumber: output software SPSS 16.00, 2012

Dari Tabel KMO and Bartlett's Test di atas, didapatkan nilai MSAsebesar 0.552 (data sample cukup untuk difaktorkan) dan nilai signifikansi sebesar 0.000 di bawah batasan maksimum 0.05 (memenuhi syarat bahwa variabel saling berkorelasi). Dari hal tersebut maka proses analisis faktor bisa dilanjutkan.

\section{Penentuan Jumlah Faktor dan Pengelompokan Variabel}

Penentuan jumlah faktor dapat dilakukan dengan melihat nilai eigenvalue dalam Tabel Total Varian Explained, dimana jumlah faktor hasil analisis faktor adalah sejumlah faktor dengan nilai eigenvalue lebih besar dari 1,00.

Tabel 3. Total Varian Explained

\begin{tabular}{|c|c|c|c|c|c|c|c|c|c|}
\hline \multicolumn{10}{|c|}{ Total Variance Explained } \\
\hline \multirow{2}{*}{$\begin{array}{c}\text { Com po } \\
\text { nent }\end{array}$} & \multicolumn{3}{|c|}{ Initial Eigenvalues } & \multicolumn{3}{|c|}{$\begin{array}{c}\text { Extraction Sums of Squared } \\
\text { Loadings }\end{array}$} & \multicolumn{3}{|c|}{$\begin{array}{c}\text { Rotation Sums of Squared } \\
\text { Loadings }\end{array}$} \\
\hline & Total & $\begin{array}{c}\% \text { of } \\
\text { Varia- } \\
\text { nce }\end{array}$ & $\begin{array}{l}\text { Cumu- } \\
\text { lative \% }\end{array}$ & Total & $\begin{array}{l}\% \text { of } \\
\text { Vari- } \\
\text { ance }\end{array}$ & $\begin{array}{l}\text { Cumu- } \\
\text { lative } \%\end{array}$ & Total & $\begin{array}{l}\% \text { of } \\
\text { Vari- } \\
\text { ance }\end{array}$ & $\begin{array}{l}\text { Cumu- } \\
\text { lative \% }\end{array}$ \\
\hline 1 & 8.113 & 32.451 & 32.451 & 8.113 & 32.451 & 32.451 & 3.447 & 13.790 & 13.790 \\
\hline 2 & 2.903 & 11.611 & 44.061 & 2.903 & 11.611 & 44.061 & 3.317 & 13.267 & 27.057 \\
\hline 3 & 2.151 & 8.602 & 52.663 & 2.151 & 8.602 & 52.663 & 2.992 & 11.969 & 39.026 \\
\hline 4 & 1.628 & 6.511 & 59.174 & 1.628 & 6.511 & 59.174 & 2.897 & 11.587 & 50.613 \\
\hline 5 & 1.540 & 6.159 & 65.333 & 1.540 & 6.159 & 65.333 & 2.404 & 9.616 & 60.229 \\
\hline 6 & 1.280 & 5.118 & 70.451 & 1.280 & 5.118 & 70.451 & 2.286 & 9.144 & 69.373 \\
\hline 7 & 1.056 & 4.226 & 74.676 & 1.056 & 4.226 & 74.676 & 1.326 & 5.303 & 74.676 \\
\hline 8 & .945 & 3.781 & 78.458 & & & & & & \\
\hline 9 & .854 & 3.414 & 81.872 & & & & & & \\
\hline 10 & .704 & 2.815 & 84.687 & & & & & & \\
\hline 11 & .669 & 2.677 & 87.364 & & & & & & \\
\hline 12 & .613 & 2.452 & 89.816 & & & & & & \\
\hline 13 & .423 & 1.691 & 91.508 & & & & & & \\
\hline 14 & .362 & 1.447 & 92.954 & & & & & & \\
\hline 15 & .317 & 1.268 & 94.222 & & & & & & \\
\hline 16 & .273 & 1.094 & 95.316 & & & & & & \\
\hline 17 & .239 & .957 & 96.273 & & & & & & \\
\hline 18 & .225 & .902 & 97.175 & & & & & & \\
\hline 19 & .197 & .790 & 97.965 & & & & & & \\
\hline
\end{tabular}




\begin{tabular}{|c|c|c|c|c|c|c|c|c|c|}
\hline \multicolumn{10}{|c|}{ Total Variance Explained } \\
\hline \multirow[b]{2}{*}{$\begin{array}{c}\text { Com po } \\
\text { nent }\end{array}$} & \multicolumn{3}{|c|}{ Initial Eigenvalues } & \multicolumn{3}{|c|}{$\begin{array}{c}\text { Extraction Sums of Squared } \\
\text { Loadings } \\
\end{array}$} & \multicolumn{3}{|c|}{$\begin{array}{l}\text { Rotation Sums of Squared } \\
\text { Loadings } \\
\end{array}$} \\
\hline & Total & $\begin{array}{c}\% \text { of } \\
\text { Varia- } \\
\text { nce }\end{array}$ & $\begin{array}{l}\text { Cumu- } \\
\text { lative \% }\end{array}$ & Total & $\begin{array}{l}\% \text { of } \\
\text { Vari- } \\
\text { ance }\end{array}$ & $\begin{array}{l}\text { Cumu- } \\
\text { lative \% }\end{array}$ & Total & $\begin{array}{l}\% \text { of } \\
\text { Vari- } \\
\text { ance }\end{array}$ & $\begin{array}{l}\text { Cumu- } \\
\text { lative \% }\end{array}$ \\
\hline 20 & |.157. & .627 & 98.592 & & & & & & \\
\hline 21 & .118 & .472 & 99.064 & & & & & & \\
\hline 22 & .088 & .351 & 99.415 & & & & & & \\
\hline 23 & .078 & .313 & 99.728 & & & & & & \\
\hline 24 & .048 & .191 & 99.919 & & & & & & \\
\hline 25 & .020 & .081 & 100.000 & & & & & & \\
\hline
\end{tabular}

Extraction Method: Principal Component Analysis.

Sumber: output software SPSS 16.00, 2012

Dari tabel tersebut dijelaskan bahwa dengan metode ekstraksi PCA (principal component analysis), dari 25 variabel yang dianalisis, dihasilkan7 faktor yang memiliki eigenvalue lebih dari 1,00 . Artinya dari 25 variabel oleh analisis faktor diperasikan menjadi hanya 7 faktor saja. Pengurangan jumlah ini mengurangi informasi dimiliki oleh keseluruhan variabel.

Ketujuh faktor hasil ekstraksi dengan metode PCA tersebut memiliki kontribusi yang berbeda-beda. Kemampuan menjelaskan dari masing-masing faktor terhadap keseluruhan variasi adalah bahwa faktor 1 hingga 7 menjelaskan sebesar 32,45\%; 11,61\%; 8,60\%; 6,51\%; 6,20\%; 5,12\%dan 4,23\% variasi. Keseluruhannya mampu menjelaskan 74,68\% variasi. Setelah dilakukan Rotasi Varimax dan Normalisasi Kaiser, kontribusinya menjadi sebesar $13,79 \% ; 13,27 \% ; 11,97 \% ; 11,59 \% ; 9,62 \% ; 9,14 \%$ dan5,30\% variasi. Total tetap menjelaskan $74,68 \%$ dari keseluruhan variasi karena sifatnya yang meringkas informasi. Dengan demikian masih ada faktor lain yang tidak termasuk dalam 7 faktor tersebut dengan muatan informasi sebesar 25,32\% dari perolehan informasi dari survei di lapangan. Informasi ini ada dalam 18 faktor. Dengan kontribusi minimal 0,081\% hingga maksimal 3,781\% informasi tiap faktor dan bisa dianggap tidak signifikan.

\section{Pengelompokan Variabel-variabel dalam Faktor}

Faktor yang terbentuk merupakan perwujudan dari pengelompokan unsur-unsur dari keseluruhan 25 variabel dengan proporsi yang berbeda. Pengelompokan variabel ke dalam faktor terlihat dari nilai loading factor dari tiap variabel di dalam 7 faktor yang terbentuk pada tabel Component Matrix tetapi ternyata masih banyak variabel yang belum mengarah pada faktor tertentu, hampir seluruh variabel bergabung dalam faktor 1. Ini tidak membantu mendapatkan faktor yang dominan pengaruhnya. Pengelompokan yang lebih tegas ada dalam tabel Rotated Component Matrix, dengan melihat posisi loading factor maksimal dari tiap variabel dan menyembunyikan loading factor yang lain, serta mengurutkan faktor sesuai kontribusinya, maka jelas terlihat dalam tabel 4 berikut. 
Tabel 4. Pengelompokan Variabel dalam Faktor

\begin{tabular}{|c|c|c|c|c|c|c|c|}
\hline \multirow{2}{*}{$\begin{array}{c}\text { Pengelompokan } \\
\text { Variabel }\end{array}$} & \multicolumn{7}{|c|}{ Faktor } \\
\hline & 1 & 2 & 3 & 4 & 5 & 6 & 7 \\
\hline 23.Tindakan.Bersama & .791 & & & & & & \\
\hline 25.Kaderisasi & .781 & & & & & & \\
\hline 14.Dukungan.Pemb & .702 & & & & & & \\
\hline 11.Situasi.Ekonomi.Intl & .626 & & & & & & \\
\hline 19.Peran.Pemda & & .844 & & & & & \\
\hline 06.Komunikasi & & .682 & & & & & \\
\hline 21.Kemitraan.PSM & & .666 & & & & & \\
\hline 05.Transportasi & & .605 & & & & & \\
\hline 12.Kapasitas.Pemda & & .549 & & & & & \\
\hline 08.Teknologi & & & .855 & & & & \\
\hline $01 . \mathrm{SDA}$ & & & .697 & & & & \\
\hline 03.Investasi & & & .593 & & & & \\
\hline 09.Ukuran.Klaster & & & .488 & & & & \\
\hline 15.Manajemen.Keu & & & & .756 & & & \\
\hline 07.Komposisi.Industri & & & & .724 & & & \\
\hline 16.Permodalan & & & & .639 & & & \\
\hline 22.Identitas.Lokal & & & & & .818 & & \\
\hline 20.Eko.Efisiensi & & & & & .774 & & \\
\hline 24.Modal.Sosbud & & & & & .644 & & \\
\hline $02 . \mathrm{Sdm}$ & & & & & & .745 & \\
\hline 18.Pemasaran & & & & & & .571 & \\
\hline 17.Produksi & & & & & & .545 & \\
\hline 04.Kewirausahaan & & & & & & .487 & \\
\hline 10.Pasar.Ekspor & & & & & & & .616 \\
\hline 13.Belanja.Pemerintah & & & & & & & -.602 \\
\hline
\end{tabular}

Sumber: Olahan Penulis dari Output SPSS, 2013

Dari tabel di atas sangat jelas bagaimana 25 variabel itu mengelompokkan diri dalam 7 faktor. Sesuai variabel yang membentuknya, maka faktor-faktor tersebut dapat diberi nama sebagai berikut:

1. Faktor 1 dapat dinamai kinerja pelaku usaha

2. Faktor 2 dapat dinamai dukungan pemda

3. Faktor 3 dapat dinamai pemanfaatan sumber daya

4. Faktor 4 dapat dinamai manajemen perusahaan

5. Faktor 5 dapat dinamai karakteristik sosial

6. Faktor 6 dapat dinamai kekuatan bisnis lokal

7. Faktor 7 dapat dinamai pembelian non lokal.

Pemberian nama 7 faktor di atas dilakukan dengan memilih nama yang mencerminkan variabel-variabel utama yang menjadi unsur-unsurnya. Dalam hal ini dimungkinkan suatu variabel yang sangat berbeda dengan nama faktornya. 


\section{Posisi Variabel dalam Faktor Utama}

Posisi masing-masing variabel dalam 3 faktor utama dapat dilihat dalam Gambar 2 Componen Plot in Rotated Spase. Gambar tersebut menjelaskan kontribusi masing-masing variabel pada tiap faktor 1, faktor 2 dan faktor 3. Nilai kontribusi tersebut berkisar antara negatif 1 hingga positif 1 . Nilai positif berarti sebanding dengan faktor, nilai negatif berarti berbanding terbalik dengan faktor. Nilai mendekati 1 menunjukkan kontribusi besar, mendekati 0 menunjukkan kontribusi yang kecil.

\section{Component Plot in Rotated Space}

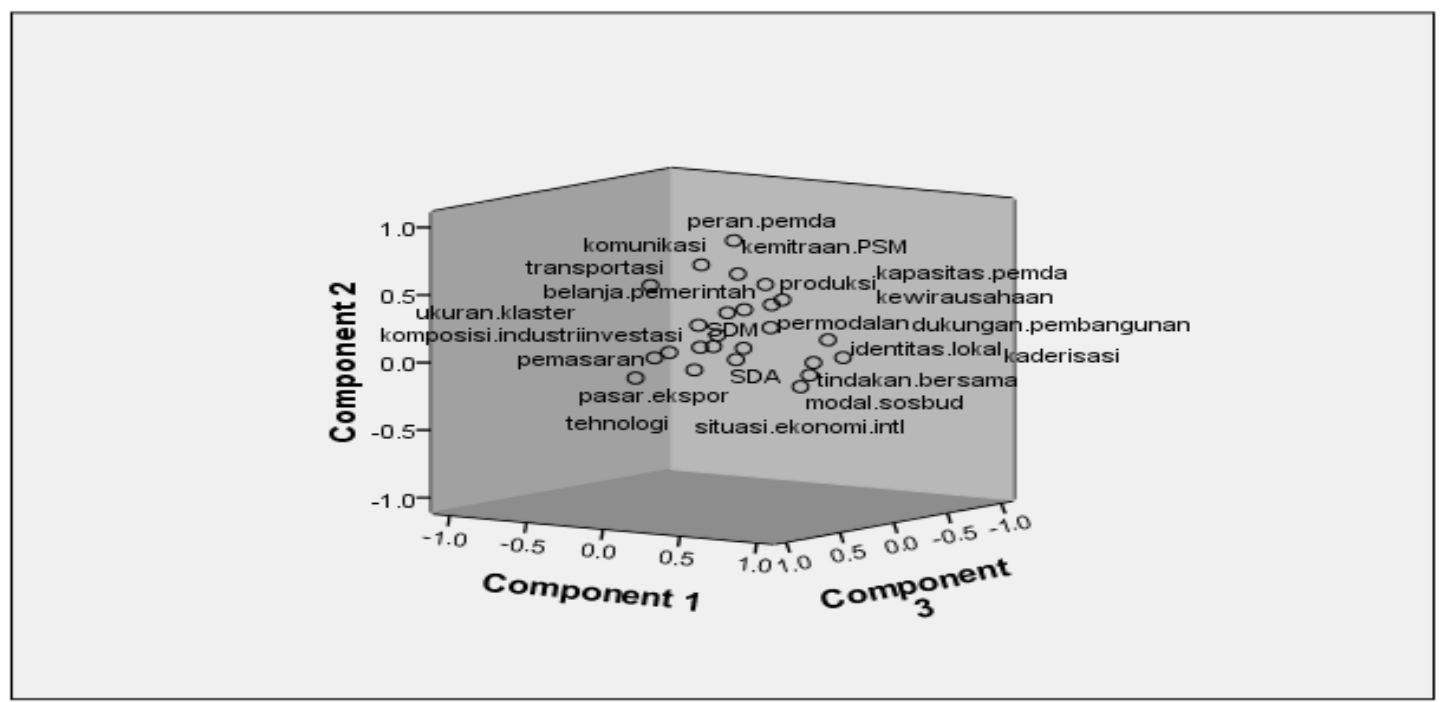

Sumber: output software SPSS 16.00, 2012

\section{Gambar 2. Plot Loading Factor Variabel - Faktor}

Secara keseluruhan, dari 25 variabel yang dianalisis dihasilkan 7 faktor hasil analisis yang umumnya merupakan penggabungan dari faktor awal. Dari 25 faktor tersebut, ada 2 faktor yang gugur yaitu kewirausahaan (4) dan ukuran klaster (9), sisanya (23 faktor) menggabung dalam 7 faktor hasil analisis.

\section{Kesimpulan}

Dari penelitian ini, kesimpulan yang dapat diambil adalah sebagai berikut:

1. Dari 25 faktor (variabel) yang diujikan di lapangan, maka terdapat 7 faktor yang berpengaruh dalam pengembangan klaster Batik Laweyan menuju ekonomi lokal berkelanjutan yaitu:

1). Faktor 1 sebesar $13,79 \%$ dapat disebut faktor kinerja pelaku usaha

2). Faktor 2 sebesar 13,27\% dapat disebut faktor dukungan pemda

3). Faktor 3 sebesar $11,97 \%$ dapat disebut faktor pemanfaatan sumber daya

4). Faktor 4 sebesar $11,59 \%$ dapat disebut faktor manajemen perusahaan

5). Faktor 5 sebesar $9,62 \%$ dapat sebut faktor karakteristik sosial

6). Faktor 6 sebesar 9,14\% dapat disebut faktor kekuatan bisnis lokal

7). Faktor 7 sebesar $5,30 \%$ dapat disebut faktor pembelian non lokal

2. Dari 7 faktor di atas mewakili $74,68 \%$ dari keseluruhan variabel yang diuji. Faktor lain sebesar 25,32\% yang ikut mempengaruhinya, tidak termasuk dalam 7 faktor tersebut 


\section{Faktor yang Mempengaruhi Pengembangan Klaster Batik Laweyan-Surakarta}

karena analisis dalam penelitian ini meringkas informasi untuk mendapatkan yang paling faktor dominan.

3. Faktor kinerja pelaku usaha merupakan faktor yang paling dominan. Faktor ini memiliki variabel utama berupa tindakan bersama untuk kepercayaan serta kaderisasi. Ini menunjukkan bahwa yang paling penting untuk mendapat perhatian adalah pengusahanya.

\section{Daftar Pustaka}

Blair, John P, 1995, Local Economic Development: Analysys and Practice, Thousand Oaks: SAGE Publications.

Blakely, Edward.J., 1994, Planning Local Economic Development.Theory and Practice. Second Edition, CA: Sage Publications Inc.

BPS. 2011. Kecamatan Laweyan Dalam Angka 2010, BPS Surakarta.

Brenner,Thomas, 2004, Local Industrial Cluster: Existence, Emergence and Evolution, London: Routledge.

Buchori, Imam et.al, 2007, Metode Analisis Perencanaan, Buku Ajar Mata Kuliah (Draft), Semarang: JPWK FT Undip

Creswell, John W. (2009). Reseacrh Design: Qualitative, Quantitative, and Mixed Methodes Approaches (3rd Ed.). Thousand Oaks, CA: Sage.

Dillon, William R and Goldstein, Matthew, 1984, Multivariate Analysis Methode and Applications, New York: John Wiley \& Sons.

Adi, Ganug Nugroho dan Alpha Fabela Priyatmono: “Arsitek Kampung Batik Laweyan”, Kabar SoloRaya.com (diunggah 29 Mei 2012 oleh tanpatinta, diunduh 16 Juni 2012).

Haeruman, Herman. Js. "Pengembangan Ekonomi Lokal Melalui Pengembangan Lembaga Kemitraan Pemerintah, Swasta, dan Masyarakat”. Sosialisasi Nasional Program Kemitraan Bagi Pengembangan Ekonomi Lokal.Hotel Indonesia, 2001.

Kusmayadi \& Sugiarto, Endar, 2000, Metode Penelitian dalam Bidang Kepariwisataan, Jakarta: Gramedia Pustaka Utama.

Mlayadipuro, 1984, Sejarah Kyai Ageng Anis-Kyai Ageng Laweyan. Urip-Urip, Surakarta : Museum Radya Pustaka.

Murti, Adhi Isa. 2010. "Peran Pemerintah Daerah dalam Pengembangan Klaster Batik Laweyan”, dalam Jurnal Tataloka, Vol. 12 No.1 Edisi , hal. 55-62

Phillips, P.D., 1990, Economic Development for Small Communities and Rural Areas.

Serageldin, Ismail, 1996, Sustainability as Opportunity and the Problem of Sosial Capital, Brown Journal of World Affairs, 3 (2)

Sforzi, Fabio, 2003, The Institutions of Local Development,

Siagian, Sondang P, 1996, Administrasi Pembangunan, Jakarta: PT. Toko Gunung Agung.

Siswanti, 2007, Faktor-Faktor yang Mempengaruhi Perkembangan Industri Batik di Kawasan Sentra Batik Laweyan Solo,

Wheeler, Stephen M. 2004, Planning for Sustainability: Creating livable, equitable, and ecological communities, London \& New York: Routledge-Taylor \& Francis Group.

Widodo, Nurrizki Dwianto, 2011. "Identifikasi Bentuk penerapan Eko-efisiensi pada Klaster Batik Laweyan Kota Surakarta", Tugas Akhir Jurusan Perencanaan Wilayah dan Kota FT Undip Semarang

World Conservation Strategy, 1980, United Nations Environment Programme (UNEP), International Union for Conservation of Nature and Natural Resources (IUCN), \& World Wide Fund for Nature (WWF). 